\title{
Refleksje nad ciążą i porodem. Perspektywa krytycznej analizy dyskursu
}

\section{KEYWORDS}

pregnancy, childbirth, medicalization, critical discourse analysis

\begin{abstract}
Nowakowska Luiza, Refleksje nad ciążą i porodem. Perspektywa krytycznej analizy dyskursu [Reflections on Pregnancy and Childbirth. The Perspective of Critical Discourse Analysis]. Kultura - Społeczeństwo Edukacja nr 1(5) 2014, Poznań 2014, pp. 9-24, Adam Mickiewicz University Press. ISBN 978-83-232-2821-9. ISSN 2300-0422

The topic of discussion is the discourse that shapes around pregnancy and childbirth in the past about two hundred years in Western countries - the mechanisms of its development, the most important manifestations and possible consequences. Theoretical basis for this problem is - Critical Discourse Analysis (CDA), and the main inspiration was the concept of M. Foucault - how according to the author this discourse is constructed, imposed and reproduced. "(...) in every society the production of discourse is at once controlled, selected, organized and subjected to redistribution by a number of procedures, whose role is to (...) take over the randomness of events (...)" writes Foucault. The purpose of the following discussion is, therefore, an attempt to show these "procedures" - methods and measures that are imposing and strengthen the medical discourse on pregnancy, childbirth, and more broadly the female body.
\end{abstract}

Przedmiotem rozważań jest dyskurs, jaki kształtował się wokół ciąży i porodu w ciągu ostatnich około dwustu lat w krajach zachodnich - mechanizmy jego rozwoju, najważniejsze przejawy oraz możliwe konsekwencje. Za podstawę teoretyczną dla tak sformułowanego problemu przyjęto krytyczną analizę dyskursu (CDA - Critical Discourse Analysis), natomiast główną inspirację stanowiła koncepcja M. Foucaulta - to, w jaki sposób, według tego autora, dyskurs jest konstruowany, reprodukowany i narzucany: „(...) w każdym społeczeństwie wytwarzanie dyskursu jest równocześnie kontrolowane, selekcjonowane, organizowane i poddane redystrybucji przez pewną liczbę procedur, których rolą jest (...) zawładnąć przypadkowością zdarzeń (...)" (Foucault, 2002: 7) - pisze Foucault. Celem poniższych rozważań jest zatem próba ukazania tych „procedur” - metod 
i środków, które służą narzucaniu i umacnianiu medycznego dyskursu dotyczącego ciąży, porodu, a szerzej - także ciała kobiety.

Na początku należałoby rozstrzygnąć, na ile podejście Foucaulta wpisuje się w programowe założenia CDA. Badacze tego nurtu, prowadząc krytycznie zorientowane analizy, przyjmują najczęściej określone stanowisko etyczne, moralne czy polityczne, stając się rzecznikami ofiar uzurpacji władzy i społecznej niesprawiedliwości. Co więcej, programowa niezgodna na krzywdę społeczną zakłada także potrzebę formułowania propozycji rozwiązań określonego problemu jako końcowego rezultatu procesu badawczego. Tymczasem w przypadku Foucaulta trudno mówić o reprezentacji konkretnego nurtu teoretycznego, zdecydowanym stanowisku politycznym czy promowaniu określonej wizji społeczeństwa (Jabłońska 2006; van Dijk, 2009). Foucault, przyjmując założenie, że wiedza jako taka nie ma kumulatywnego charakteru, neguje samą ideę postępu w pozytywistycznym znaczeniu. $\mathrm{Z}$ tego punktu widzenia określone systemy myślowe stanowią dla niego manifestacje pewnego sposobu interpretacji rzeczywistości bez uzurpowania sobie prawa do bycia tą jedyną prawomocną. A zatem, historyczne „odmiany” wiedzy interesują Foucaulta w sposób szczególny: jako zakorzenione w konkretnym miejscu i czasie interpretacje świata, których nie weryfikuje i nie ocenia on według kryterium prawdy i fałszu (Czerwiński, 1987). W tym sensie postulat CDA dotyczący zaangażowania nie znajduje odzwierciedlenia w myśli naukowej i postawie badawczej Foucaulta. Pomimo tej rozbieżności, odwołania do jego dorobku w badaniach CDA nie są wcale rzadkie. Wręcz przeciwnie, sytuując dyskurs $\mathrm{w}$ centrum swojego zainteresowania oraz podkreślając rolę języka w konstruowaniu rzeczywistości społecznej (Jabłońska 2006; van Dijk, 1993), Foucault zdecydowanie mieści się w tym nurcie badawczym. CDA, badając określony problem, zwraca szczególną uwagę na niejawne mechanizmy władzy i manipulacji, które przejawiają się na różne sposoby w publicznym dyskursie. Metoda ta stawia sobie zatem za cel odkrycie powiązań między sposobem konstruowania dyskursu a stosunkami panującymi w społeczeństwie (Huckin, 2002), poszukiwanie „(...) relacji między tekstem, rozmową (...), władzą, społeczeństwem i kulturą" (van Dijk, 2006: 253). Takie podejście badawcze oddaje intencję Foucaulta, który zainteresowany był poznawaniem „wewnętrznej organizacji dyskursu”, jego „architekturą”, w celu demistyfikacji ukrytych powiązań między władzą a wiedzą (Czerwiński, 1987; Huckin, 2002).

Warto zwrócić uwagę na fakt, że CDA nie stanowi jednorodnej perspektywy opartej na precyzyjnie ustalonych technikach badawczych i trudno przypisać ją 
do konkretnego kierunku teoretycznego, a tym bardziej wybranego autora. CDA, badając związek między dominacją a dyskursem, między „przestrzenią językową” a panowaniem, oraz analizując źródła nierówności i niesprawiedliwości społecznej, z założenia stanowi orientację o charakterze multidyscyplinarnym (van Dijk, 2002). Niejednoznaczność metodologiczną i teoretyczną potęguje ponadto bogactwo znaczeniowe samego pojęcia dyskursu - może być on rozumiany jako sposób komunikacji reprezentowany w tekście lub ustnej wypowiedzi, ale także jako specyficzne użycie języka (np. dyskurs feministyczny, polityczny). Dyskurs stosowany jest również zamiennie $\mathrm{z}$ takimi terminami, jak dyskusja, debata, język czy komunikacja. Stąd też w ramach CDA odnaleźć można wiele różnych podejść i orientacji - m.in. socjologiczną, lingwistyczną, krytyczną. Według przedstawicieli tego nurtu, niejasny status krytycznej analizy dyskursu nie powinien jednak zniechęcać do jej uprawiania, wręcz przeciwnie, pozwala na on pewną swobodę w doborze zarówno technik badawczych, jak i „zaplecza teoretycznego” - CDA to podejście, „(...) w którym samo rozróżnienie na teorię, opis i zastosowanie staje się mniej istotne" (Jabłońska, 2006: 57) To, co łączy badaczy CDA, to zainteresowanie tym, w jaki sposób sfera komunikacji i „produkowana” wiedza wchodzą w relację ze światem społecznym, przenikają systemy władzy i sprawiają, że jedni są wykluczani, a drudzy wykluczający (van Dijk, 2002). $\mathrm{Z}$ tego punktu widzenia, wybór koncepcji Foucaulta jako podstawy teoretycznej dla poniższych rozważań można uznać za jak najbardziej uzasadniony.

\section{Ciało kobiety jako obszar walki o dominację}

Według Foucaulta, jedną z częściej stosowanych metod „ujarzmiania” społeczeństwa jest wykluczanie poprzez wprowadzanie opozycji „zdrowe - chore”, „normalne - patologiczne”, „prawdziwe - fałszywe”. Zwraca się uwagę, że medyczne zainteresowanie ciałem kobiety wynikało właśnie z dostrzeżenia jej biologicznej odrębności oraz zdefiniowania tej różnicy jako odstępstwa od męskiej „normalności”. Mechanizm, który Foucault nazywa „podziałem i odrzuceniem”, doprowadził do upowszechnienia wizji ciała kobiety jako metafory niestabilności, impulsywności, potencjalnego zagrożenia, czegoś, co wymagało specjalnego traktowania oraz stałej kontroli: w podręcznikach medycznych XIX i XX wieku poznawanie ciała człowieka zaczyna się właśnie od standardowego ciała męskiego, ciało kobiece z kolei reprezentuje ciało „inne”, odbiegające od normy - np. 
nierównowagę hormonalną, źródło chorób wenerycznych czy wad genetycznych potomstwa (Foucault, 2002; Buczkowski, 2005).

W koncepcjach feministycznych zwraca się uwagę, że wyrazem wzrastającego medycznego zainteresowania ciałem kobiety był m.in. spektakularny rozwój ginekologii, któremu nie towarzyszyło powołanie analogicznej dziedziny dla mężczyzn (andrologia powstała dopiero w latach 70. XX wieku i nawet obecnie nie jest tak rozwinięta i znana jak ginekologia). Istnieją także poglądy, że endokrynologia, skupiając się właściwie wyłącznie na kobiecie, także przyczyniła się do wzmocnienia sposobu jej postrzegania jako podatnej na działanie sił natury bardziej niż rozumu. W latach 20. i 30. XX wieku zaczęto stosować terapie hormonalne regulujące cykl menstruacyjny, menopauzę oraz płodność. Leczono w ten sposób także osoby homoseksualne, definiując tym samym te dwie grupy społeczne jako „fizjologicznie rozchwiane” - w przeciwieństwie do mężczyzn, którzy reprezentowali „stabilną” część społeczeństwa. Innym przykładem medycznej kontroli kobiecej cielesności jest histeria, którą w połowie XIX wieku wiązano z zakłóceniami narządów rodnych kobiety, czyniąc to zaburzenie przypadłością jednej płci. Rozszerzono ponadto jej diagnozę na takie kobiece zachowania, które nie mieściły się w przyjętej normie, jak sprzeciw czy niekonwencjonalne postępowanie. Objawy niesubordynacji zwalczano różnego rodzaju terapiami, włącznie z wycinaniem jajników. Kolejnym przykładem są koncepcje rozwijane pod koniec XIX wieku, w ramach których argumentowano, że próby przejęcia kontroli nad życiem rozrodczym i seksualnym kobiet przez wczesne ruchy feministyczne będzie skutkowało bezpłodnością, a nawet wzrostem samobójstw (Buczkowski, 2005; Gromkowska-Melosik, 2013).

Powyższe przykłady ukazują, w jaki sposób medycyna, działająca w relacji z władzą i ją reprezentująca, wkroczyła w życie codzienne kobiet, legitymizując jednocześnie ówczesny porządek społeczny. Rozwój dyskursu medycznego należałoby zatem odczytywać nie tylko jako walkę o uznanie pewnej interpretacji rzeczywistości, ale także walkę płci, w której „(...) regulacja kobiecej mocy reprodukcyjnej, (...) prawna i technologiczna kontrola mężczyzn nad antykoncepcją, płodnością, aborcją i położnictwem, ginekologią oraz eksperymenty nad zapłodnieniem pozamacicznym (...)" utrwalają hierarchię społeczną opartą na płciowym podziale ról (Rich, 2000: 73). Zatem o ile do połowy XVIII wieku odmienna sytuacja kobiet i mężczyzn wynikała $\mathrm{z}$ pewnego systemu wartości i wizji porządku społecznego, w wieku XIX wskazywano na cechy biologiczne jako uzasadnienie miejsca zajmowanego w strukturze społecznej. Medycyna, dostarczając 
argumentów naukowych mających świadczyć o „inności” i „nienormalności” kobiecego ciała i procesów, które w nim zachodzą, sankcjonowała podrzędną pozycję społeczną kobiet. Przyjmując rolę gwaranta panujących stosunków, stała się więc jednym z ważniejszych źródeł utrwalania nierówności społecznych (Buczkowski, 2005).

\section{Instyłucjonalizacja i technologizacja narodzin człowieka}

Irving Kenneth Zola, analizując medycynę jako formę kontroli społecznej, zauważa, że jeszcze na początku XX wieku zdecydowana większość porodów w Stanach Zjednoczonych miała miejsce poza instytucją szpitala - w roku 1900 zaledwie 5\% porodów przyjmowano w szpitalu, podczas gdy w roku 1935 stanowiły one już 75\% wszystkich porodów (Zola, 1972; Podgórska, 2005). Dynamiczną instytucjonalizację narodzin człowieka, jaka nastąpiła w ciągu minionego stulecia, można potraktować jako zasadniczy element dyskursu medycznego, jaki kształtował się wokół ciąży i porodu. Foucault, śledząc mechanizmy rozwoju dyskursu, podkreśla, że dokonuje się on w oparciu o różnego rodzaju instytucje - może to być system edukacji, towarzystwa nauk czy instytucje medyczne. To za ich pośrednictwem zachodzi ów subtelny przymus oraz przenikanie obowiązującej wiedzy. Medyczne podejście do ciąży i porodu można zatem traktować jako rezultat ścierania się różnych „odmian wiedzy”, prawdę kształtowaną w procesie „dystrybucji instytucjonalnej” (Foucault, 2002: 12-13).

Spektakularny rozwój położnictwa szpitalnego, marginalizując lub negując alternatywne rozwiązania, sprawił, że ciąża i poród stały się domeną lekarzy, obszarem, gdzie jedynym uznanym autorytetem jest medycyna. Przeniesienie porodów do szpitali doprowadziło do zasadniczego podziału między tym, co medyczne (a więc „właściwe”, „normalne”, „naukowe”), a tym, co niemedyczne („niepewne”, „nieobiektywne”, „nieprofesjonalne”, „nieskuteczne”). Proces ten dokonał się poprzez wprowadzenie normy jako kryterium prawidłowego podejścia do procesu narodzin. Poród w szpitalu uznano za zgodny z normą, porody poza systemem medycznym poddano natomiast stygmatyzacji i zdefiniowano jako dewiacyjne, ryzykowne, zacofane, niehigieniczne. $Z$ tej perspektywy wyłącznie medycyna, ze swoją technologią, standardami i procedurami, była w stanie ten chaos uporządkować i nadać mu konkretny kształt (Podgórska, 2005).

Zanim dyskurs medyczny zdominował ten aspekt życia, ciąża, poród i okres połogu postrzegane były w sposób wieloaspektowy - nie tylko jako biologiczny 
stan, ale także ważny element życia danej społeczności, obudowany licznymi rytuałami, obrzędami i mitami. Normy społeczne, kulturowe, a także religijne regulowały między innymi wybór miejsca porodu, osoby towarzyszące, preferowaną pozycję rodzenia czy sposób traktowania matki po porodzie. Narodziny dziecka symbolizowały ciągłość trwania społeczności, a dla kobiety i całej rodziny stanowiły błogosławieństwo, kluczowy moment przejścia oraz nabycia nowej pozycji społecznej (Domańska, 2005). W wyniku postępującej instytucjonalizacji, ciążę i poród zredukowano do wymiaru biomedycznego, jako przedmiot ustalonych przez ekspertów (lekarzy) czynności medycznych (Cahill, 2000). Zwraca się uwagę, że przeniesienie porodów na sale szpitalne doprowadziło do „wyrwania” tego wydarzenia z kontekstu społeczno-kulturowego, wyłączenia z naturalnego środowiska życia oraz separacji porodu od domeny doświadczeń wspólnotowych. Tak rozumiane wykorzenienie dotyczy także problemu wykluczenia najbliższych $\mathrm{z}$ aktu narodzin - kobieta w murach szpitala przeżywa poród samotnie; doświadczenie zbiorowe staje się procedurą medyczną, na której zna się wyłącznie lekarz, elementem wielkiej anonimowej biurokratycznej machiny, w której brakuje miejsca na indywidualizm i podmiotowe traktowanie. Przyjęcie do porodu oznacza bowiem poddanie rygorowi pracy szpitala, któremu kobieta rodząca musi się poddać: „(...) golenie, mycie, lewatywa, spłukanie środkiem antyseptycznym, rzeczy do depozytu. Potem izolacja: kobiety od rodziny, matki od dziecka. Więzienny dryl i pełne podporządkowanie" (Podgórska, 2005: 4). W ten sposób poród przestał być aktem indywidualnym o niepowtarzalnej dynamice, opartym na siłach natury z aktywną rolą kobiety, a stał się mechanicznym zabiegiem wydobycia dziecka $\mathrm{z}$ ciała matki, dostosowanym do rytmu i stylu pracy danego szpitala (Rich, 2000).

Wraz z przeniesieniem porodów do szpitala dokonała się ponadto ich patologizacja. Każdy poród traktowany jest jako niebezpieczny, zagrażający życiu matki i dziecka, wymagający, oprócz stałej obecności lekarza, stosowania wszelkich dostępnych środków medycznych mających to ryzyko redukować do minimum. Stwarza to sytuację, kiedy wiele procedur i interwencji stosowanych jest rutynowo do każdej, także tej niezagrożonej, ciąży jako zwykły element pracy szpitala. Przykładem tego typu praktyk są między innymi „taśmowe” stosowanie farmakologicznych środków uśmierzania bólu, chemiczna stymulacja akcji porodowej, wymuszanie pozycji horyzontalnej, a także oddzielanie matki od dziecka i opóźnianie pierwszego karmienia piersią (Rich, 2000). Ponadto, sam fakt przebywania w szpitalu narzuca sposób zachowania zgodny z wyznaczoną insty- 
tucjonalnie rolą - rolą chorego. A zatem, kobieta rodząca staje się automatycznie pacjentem i jest to rola niepozbawiona pewnych istotnych znaczeń: „W sensie ściśle etymologicznym "pacjent» oznacza osobę cierpiącą, będącą obiektem działania (...), jest w sytuacji «otrzymującego». Reaguje, a nie podejmuje inicjatywy; jest przeciwstawieniem «działającego»" (Gallagher, 1976: 195).

\section{Traumatyzacja porodu}

Ważnym elementem dyskursu medycznego w odniesieniu do narodzin człowieka oraz istotnym narzędziem walki o dominację w tym obszarze było skojarzenie porodu z wydarzeniem traumatycznym, niosącym cierpienie, które może znieść tylko osoba $\mathrm{z}$ dużą odpornością. Obudowanie porodu aurą lęku, niepokoju i bólu stało się bodźcem dla różnego rodzaju reakcji „ucieczkowych” - począwszy od zgody na nieuzasadnione interwencje medyczne i bierne podporządkowanie procedurom, po całkowitą rezygnację z roli (np. upominanie się o cięcie cesarskie czy pełne znieczulenie) (Domańska, 2005). Antycypowanie bólu w istotny sposób przyczyniło się do umocnienia medycznego podejścia do porodu. Adrienne Rich pisze, iż: „Zaskakująco wiele kobiet (...) podchodzi do porodu z pragnieniem, by wiedzieć jak najmniej: «Tylko mnie znieczulcie i pozwólcie działać doktorowi». Sama byłam jedną z takich kobiet (...), przekonaną, że wiedza na temat mojego ciała jest sprawą «ekspertów», a rodzenie specjalnością położnika" (Rich, 2000: 192). Alternatywna wizja porodu jako wyjątkowego, wzbogacającego doświadczenia oraz źródła psychicznej siły i satysfakcji jest niezwykle rzadko spotykana (Rich, 2000: 226).

Sprowadzenie porodu do reakcji bólowych sprawiło, że medycynę zaczęto traktować jako jedyną instancję dającą poczucie bezpieczeństwa, przynoszącą pocieszenie i ukojenie. W koncepcjach feministycznych podkreśla się tymczasem, że technologie medyczne stworzyły pozór bezpieczeństwa oraz osłabiły wolę kobiet w świadomym przebiegu porodu (Balaskas, 1997). Za sprawą interwencji medycznej poród dzieje się „poza kobietą” - poza jej świadomością i intencjami. Kobiety rodzące zgodnie z modelem medycznym mają wręcz trudność w zintegrowaniu tych dwóch aspektów: ciała i umysłu, fizjologii i woli, świadomości i biologicznej determinacji. Wraz z upowszechnianiem się medycznego podejścia do porodu następuje jego kryzys jako „fizjologicznego wyzwania”, kreatywnego procesu pokonywania samej siebie przy wsparciu osób postronnych w momentach szczególnie trudnych. W zamian kobietom dawany jest sygnał, że 
akcja porodowa nie zakończy się powodzeniem bez medycznej czy farmakologicznej pomocy, a one tę interpretację przyswajają i nie dostrzegają alternatywnych rozwiązań (Reiger, Dempsey, 2006).

Umocnienie dyskursu medycznego poprzez traumatyzację porodu dokonało się przy jednoczesnym rozwoju specyficznego podejścia do bólu, traktowanego w medycynie zachodniej jako swego rodzaju wroga, agresora, z którym należy walczyć wszelkimi dostępnymi środkami. Ivan Illich, opisując negatywne oddziaływanie instytucji medycznych, zwraca uwagę na funkcjonowanie medycyny jako „moralnego przedsięwzięcia” na rzecz zwalczania bólu związanego z utratą zdrowia czy śmiercią. Zauważa on, że działając w ten sposób, medycyna odbiera cierpieniu osobiste znaczenie, przekształca je w zagadnienie i wyzwanie czysto technologiczne oraz pozbawia jednostki umiejętności konfrontacji z nim (Illich, 1976). Ból definiowany wyłącznie jako fizyczna reakcja organizmu implikuje konieczność interwencji medycznej jako normalny, oczywisty sposób postępowania. Podobnie utożsamienie porodu z cierpieniem stworzyło stałą gotowość do pozbywania się bólu wszelkimi dostępnymi środkami medycznymi. Tymczasem zwraca się uwagę, że takie podejście oznacza poważne zubożenie zarówno aktu narodzin, jak i samego bólu. W rzeczywistości stanowi on bowiem ważne, wielowymiarowe doświadczenie o złożonej etiologii i funkcjach - ma istotne znaczenie ostrzegawcze, aktywizujące, pełni rolę „przewodnika” - informuje o potencjalnym zagrożeniu, prowadzi kobietę i podpowiada, w jaki sposób uniknąć niebezpieczeństwa (np. poruszając się podczas porodu). Ból inicjuje także wydzielanie niezbędnych hormonów, które stymulują akcję porodową. Ma on także istotny wymiar psychologiczny - jego opanowanie jest warunkiem osiągania wyższego poziomu dojrzałości, funkcją osobistego rozwoju (Fijałkowski, 1974). Zwraca się zatem uwagę, że nie można łączyć porodu z bezsensownym cierpieniem, które rutynowo zwalcza się, stosując farmakologię lub cięcie cesarskie. Ponadto, jak podkreślają zwolennicy porodów zdemedykalizowanych, ból porodowy nie jest czymś jednorodnym - stanowi raczej mieszaninę odczuć fizycznych, jak i psychicznych: poczucia alienacji, lęku o przyszłość, zdrowie dziecka, związek z partnerem, obawy przed utratą niezależności, strachu przed nowymi obowiązkami. Jest zatem w dużym stopniu zapośredniczony kontekstem społecznym i kulturowym. Czyli to, jak kobiety przeżywają poród, jak reagują na ból i jaki mają do niego stosunek, wynika ze „społecznie dziedziczonego” obrazu porodu, który często utrwalany jest przez media, traumatyczne filmowe sceny porodu oraz relacje samych kobiet: „Moje wyobrażenie o bólu porodowym opie- 
rało się na obrazach z filmów. Kiedy pojawiła się konieczność wywołania porodu, a ja czekałam na izbie przyjęć, nagle zdałam sobie sprawę, że ten przerażający ból się zaraz zacznie i nie będzie miał końca, że już nie mam odwrotu” (cyt. za: Kubicka-Kraszyńska, Otffinowska, Pietrusiewicz, 2006: 11). Kulturowa definicja bólu jako drogi rozwoju, pokonywania ograniczeń, przejścia do kolejnego etapu, jako zawiłej, różnorodnej gamy doznań, a nie jednolitej „ściany” cierpienia, jest zdecydowanie mniej rozpowszechniona (Rich, 2000).

Podsumowując, poród jako metafora cierpienia stał się istotnym czynnikiem alienacji kobiety $\mathrm{z}$ procesu rodzenia - rezygnując $\mathrm{z}$ osobistego zaangażowania oraz aktywnego przeżywania porodu, zajmuje ona podrzędną pozycję względem personelu szpitalnego. W tej asymetrycznej konfiguracji lekarz jawi się jako opanowany profesjonalista oraz jedyna kompetentna osoba zdolna „urodzić” dziecko (Cahill, 2000). Kobieta natomiast odgrywa narzuconą rolę pacjenta, którą cechuje „(...) bierność, podporządkowanie, stosowanie się do zaleceń lekarskich, [udzielanie] dostępu do informacji intymnych, nieograniczonego dostępu do ciała itd.” (Domańska, 2005). W ten sposób, z aktywnego podmiotu, który zna własne ciało i ma świadomość zachodzących procesów fizjologicznych, staje się przedmiotem medycznych konsultacji i działań (Wagner, 2001).

\section{Marginalizacja zawodowa położnych}

Opisane powyżej mechanizmy upowszechniania dyskursu medycznego w odniesieniu do ciąży i porodu warto uzupełnić o jeszcze jeden aspekt - kolejną metodę walki o dominację w tym obszarze. Rozpatrywany w tym kontekście dyskurs medyczny przedstawia się często jako konkurencyjną walkę o wpływy w systemie medycznym oraz opisuje w języku rywalizacji między lekarzami a położnymi. Jak argumentują krytycy procesu medykalizacji, zapoczątkowana w XVII wieku profesjonalizacja zawodu lekarza polegała w dużej mierze na wykluczaniu: organizacje chroniące interesy tej profesji ukierunkowane były na dyskredytowanie i eliminowanie medycznych samouków poprzez wprowadzanie powszechnie obowiązujących standardów zawodowych. Instytucjonalne uprawomocnienie tego zawodu stworzyło możliwość sprawowania przez lekarza władzy społecznej - to on, jako reprezentant systemu władzy, posiadł wyłączne prawo ingerowania, nadzorowania, eliminowania różnego rodzaju „nieprawidłowości”. Z tej perspektywy tradycyjne akuszerki stały ofiarą prowadzonej przez lekarzy ofensywy (Bińczyk, 2002; Wertz, 1996). Środowisko medyczne rozpoczęło negatywną 
kampanię podważającą ich wiedzę i umiejętności jako niewystarczające, a nawet szkodliwe. Korzystanie $\mathrm{z}$ akuszerskich usług skojarzono $\mathrm{z}$ brudem, zacofaniem i zabobonem. Był to okres w historii położnictwa, kiedy odbieranie porodu oparte na doświadczeniu, tradycji i intuicji zaczęto dezawuować na rzecz „naukowej praktyki lekarskiej” (Rich, 2000: 199). Jeszcze do połowy XIX wieku zdarzało się, że doświadczone akuszerki w Stanach Zjednoczonych nauczały swojej profesji studentów medycyny. We wczesnych latach XX wieku, na skutek nacisków amerykańskich stowarzyszeń ginekologicznych, aby zakazać wydawania akuszerkom licencji, wyeliminowano je praktycznie z systemu usług położniczych. Budowanie medycznego monopolu odbywało się zatem poprzez podporządkowanie tradycyjnego położnictwa sformalizowanemu systemowi wiedzy i szkoleń, z których położne zostały w dużej mierze wyłączone (Wagner, 2006). Proces ten znajduje odzwierciedlenie w opisywanym przez Foucaulta mechanizmie umacniania dyskursu, który rozwija się „(...) przez to, jak wiedza jest stosowana w społeczeństwie, jak jest waloryzowana, rozprzestrzeniana, rozdzielana i w pewien sposób przyznawana" (Foucault, 2002: 13).

Jak wynika z powyższego, konfrontację z tradycyjnymi akuszerkami można także odczytywać jako „walkę płci” o wpływy w sferze, która przez długi czas pozostawała poza zainteresowaniem mężczyzn. Do XVII wieku ciąża i poród stanowiły domenę przede wszystkim kobiet, to one towarzyszyły rodzącej, uśmierzały bóle, radziły w sprawach życia seksualnego, antykoncepcji. Rola mężczyzn w położnictwie sprowadzała się do pomocy w przy porodach problematycznych - np. tylko lekarze mogli wykonać obrót płodu ułożonego pośladkowo. Hipokratejscy lekarze z rezerwą i bojaźnią odnosili się do dotykania kobiecych narządów rodnych, a w okresie średniowiecza odbieranie porodów było traktowane wręcz jako zajęcie „nieczyste”, poniżej męskiej godności. Z początkiem renesansu można mówić o stopniowym przejmowaniu tej profesji przez lekarzy, korzystających z szybko rozwijającej się wiedzy naukowej z zakresu anatomii i fizjologii kobiecego ciała (Cahill, 2000; Rich, 2000).

W konfrontacji dyskursu medycznego z tradycyjnym położnictwem, akuszerki oczywiście broniły własnych metod. Stawiały je w opozycji do porodu „technologicznego”, podkreślając, że są one „bliskie naturze”, opierają się na empatii, rozsądku i umiarkowanym podejściu do zdobyczy naukowych, a także są lepiej dostosowane do indywidualnych potrzeb kobiet (Rich, 2000). W pracy Treatise on the Art of Midwifery z 1760 roku Elisabeth Nihell, położna, przeciwstawiała wiedzę i kompetencje akuszerek, potwierdzone wielowiekową tradycją 
towarzyszenia kobietom rodzącym - nienaturalnej obecności mężczyzn. Przywołała w tym kontekście postać angielskiego chirurga, Williama Smelliego, który nauczał studentów, posługując się skonstruowaną przez siebie maszyną składającą się z „(...) drewnianej sylwetki przedstawiającej kobietę, której brzuch był zrobiony ze skóry, a pęcherz wyobrażał macicę. Ten pęcherz był zakorkowany (...), w środku niego leżała woskowa lalka, której nadawano różne pozycje” (cyt. za: Rich, 2000: 216). Przykład ten obrazuje dystans między rodzącą kobietą a lekarzem, reprezentującym nowoczesną wiedzę i technologię medyczną: „Był [on] bardziej technikiem niż doradcą, przewodnikiem i źródłem morale; pracował «nad» bardziej niż «Z» matką" (Rich, 2000: 218). W opinii akuszerek, zdominowanie położnictwa przez lekarzy oznaczało zatem pozbawienie kobiet tej szczególnej relacji, jaka zawiązuje się między nimi poprzez udzielanie wsparcia psychicznego oraz świadczenie opieki, czasami nawet do końca połogu.

Szczególnie czytelną ilustrację sporu między lekarzami położnikami a akuszerkami stanowi historia kleszczy porodowych zwanych „rękami z żelaza”. Stosowane od XVII wieku podczas problematycznych porodów, stały się symbolem męskiego położnictwa, eliminacji kobiet z praktyki położniczej, przeciwieństwem „rąk z krwi i kości”. Już w tamtym okresie środowisko akuszerek podnosiło kwestię bezpieczeństwa i zasadności posługiwania się tym narzędziem i oskarżało położników o rutynowe wywoływanie tą metodą przedwczesnego porodu oraz skracanie jego naturalnego przebiegu dla własnej wygody. Położne zwracały także uwagę, że tego rodzaju interwencje podejmowane są często w ramach naukowego eksperymentu, kosztem rodzących: „Nie ma wątpliwości, że narzędzie to było stosowane zbyt chętnie przez śmiałych i entuzjastycznych akuszerów i koniecznym było, by wiodący w tej profesji mężczyźni nauczali jakichś metod umiaru (...)” (cyt. za: Rich, 2000: 215).

Zdominowanie położnictwa przez lekarzy i marginalizację roli położnych wymienia się jako zasadnicze elementy rozprzestrzeniania się dyskursu medycznego w odniesieniu do ciąży i porodu. Zwraca się uwagę, że zapoczątkowany w XVII wieku proces wykluczania tradycyjnych akuszerek z nowoczesnego położnictwa doprowadził do utrzymującej się do czasów współczesnych zubożonej wizji porodu jako technicznej czynności „wydobycia” dziecka, a także do ograniczonej autonomii kobiet rodzących oraz patologizacji naturalnych, „zdrowych” procesów reprodukcyjnych. Skojarzenie tej sfery z anomalią, chorobą, dewiacją, dało podstawy do stałego medycznego (męskiego) nadzoru. Konsekwencją powyższych procesów jest utrzymująca się niska świadomość tego, kim w istocie 
jest położna, jaka jest jej rola w akcie porodu, a także podrzędna wobec lekarzy pozycja w szpitalnej hierarchii (Rich, 2000).

\section{W stronę humanizacji ciąży i porodu. Uwagi podsumowujące}

W tekście przedstawiono wybrane mechanizmy kształtowania się dyskursu medycznego, który w większości krajów rozwiniętych zdominował sposób myślenia o ciąży, porodzie i kobiecie rodzącej. W szerszym znaczeniu, dyskurs medyczny oznacza próbę „zawłaszczenia” przestrzeni społecznej poprzez traktowanie złożonych zjawisk w kategoriach biomedycznych, najczęściej jako chorobę, czynnik ryzyka lub zaburzenie. W odniesieniu do kobiet oznacza to, iż naturalne etapy życia - ciąża, poród, karmienie czy interakcja z dzieckiem - zostały w dużej mierze wyłączone $z$ kontekstu społeczno-kulturowego i poddane medycznej interpretacji (Purdy, 2001). W przypadku ciąży i porodu dyskurs medyczny przejawia się w szczególności: zubożeniem sposobu rozumienia, czym jest macierzyństwo, sprowadzeniem kobiety rodzącej do biernego obiektu medycznych interwencji, interpretacją ciąży i porodu jako zagrożenia, odebraniem rodzącej poczucia sprawstwa oraz bycia kompetentną, a tym samym utratą psychicznej satysfakcji $\mathrm{z}$ porodu, a także strachem jako motywacją do poddawania się nieuzasadnionym interwencjom, podrzędną rolą położnych w stosunku do lekarzy oraz powszechnym przekonaniem, że bezpieczny poród ma miejsce wyłącznie w szpitalu itd. (Domańska, 2005).

$\mathrm{Na}$ początku rozważań podkreślałam, że Foucault, analizując dyskurs, nie dokonywał ocen i nie wysuwał programu poprawy sytuacji ofiar zakulisowych działań władzy. Jednak wpisując się w założenia CDA, warto na koniec zwrócić uwagę na sugerowane przez różnych badaczy kierunki działań, mające na celu podważenie dominacji medycznej interpretacji ciąży i porodu. Poglądy krytyków „medycznej uzurpacji” stanowią część rozwijającego się od lat 70. XX wieku głównie w Stanach Zjednoczonych ogólniejszego ruchu kontestującego kulturę konsumpcyjną społeczeństw ponowoczesnych, w tym również skomercjalizowany system medyczny. Społeczna percepcja nastawionej na zysk, zbiurokratyzowanej i stechnicyzowanej, a przez to zagrażającej zdrowiu medycyny była wyrazem rosnącej świadomości, iż system medyczny musi być przedmiotem pozamedycznej kontroli oraz systematycznej oceny jakości usług - koszty i efektywność leczenia, błędy jatrogenne, skutki uboczne leczenia powinny być jawne i poddane osądowi społecznemu (Piątkowski, 2002). W tym kontekście, zarówno 
przedstawiciele zawodów medycznych, urzędnicy, politycy, jak i opinia publiczna, powinni dysponować pełną informacją o pozytywnych i negatywnych konsekwencjach medycznego modelu ciąży i porodu.

W 1985 roku WHO poddała krytyce lekarsko-medyczny model prowadzenia ciąży i porodu, sformułowała także zalecenia oceniające zasadność stosowania określonych procedur medycznych i formy kontroli nad nimi. Według wytycznych tej instytucji, indywidualny nadzór lekarzy czy szpitala nad porodem powinien być zastąpiony szerszym systemem opieki okołoporodowej, zbliżonym do społeczności lokalnej ${ }^{1}$. Wszystkie kobiety ciężarne, nie tylko te z grupy ryzyka, powinny być objęte zdecentralizowaną opieką, dostępną w najbliższym otoczeniu, respektującą specyficzne warunki społeczno-kulturowe, opartą na wizji porodu jako centralnego punktu życia rodziny, z możliwością szybkiego reagowania w sytuacji nieprzewidzianych komplikacji. WHO określa system tego typu jako „opiekę poziomu pierwszego” (first-level maternal and newborn care) i wymienia następujące jej cechy: bliska klienta (close-to-client), zdemedykalizowana, ale profesjonalna, dostępna dla wszystkich matek i noworodków, oparta na usługach położnych, świadczona na szpitalnych oddziałach położniczych oraz $\mathrm{w}$ ośrodkach położniczych (midwife-led facilities). Poziom opieki podstawowej powinien być kompatybilny ze wspomagającym systemem wyższego rzędu (back-up maternal and newborn care), opierającym się głównie na usługach ginekologów-położników i pediatrów, reagującym na wszystkie problemy, które nie mogą być rozwiązane na poziomie pierwszym².

W dyskusji nad optymalnym systemem opieki okołoporodowej zwraca się uwagę, iż wprowadzanie alternatywnych w stosunku do medycznego rozwiązań jest trudne do przeprowadzenia. Nie chodzi bowiem tylko o zauważenie istniejącego problemu oraz wdrażanie pewnych rozwiązań na szpitalnych salach, ale działania systemowe, podejmowane przez uświadomionych działaczy politycznych $^{3}$. Zatem prawdziwie skuteczna byłaby strategia wzajemnie powiązanych działań, wykraczających poza system stricte medyczny. Zaleca się, oprócz wzmacniania istniejącej opieki zdrowotnej, promowanie większego zaangażowania profesjonalnych położnych na podstawowym poziomie usług medycznych

${ }^{1}$ M. Wagner, Ryby nie widza wody: potrzeba humanizacji porodu, przeł. A. Lokaj. http://www. rodzicpoludzku.pl/Wiedza-o-porodzie/Ryby-nie-widza-wody-potrzeba-humanizacji-porodu.html (dostęp: 29.03.2014 r.).

${ }^{2}$ Make every mother and child count; raport WHO z 2005 roku. http://www.who.int/whr/2005/en/ (dostęp: 29.03.2014 r.).

${ }^{3}$ Tamże. 
oraz rozwijanie i inkorporację do tradycyjnych systemów zdrowotnych alternatywnych form opieki położniczej dla kobiet chcących rodzić poza szpitalem. Oprócz rozwiązań instytucjonalnych, warunkiem koniecznym osiągnięcia postawionego celu jest także otwarta dyskusja nad prawami kobiet, promocja równości płci oraz wspieranie kobiet na różnych obszarach życia społecznego (Rasch, 2007).

\section{Literatura}

Balaskas J. (1997). Poród aktywny. Nowe spojrzenie na naturalny sposób rodzenia, przeł. K. Niecikowska-Jastrzębska, J. Stępień. Warszawa.

Bińczyk E. (2002). Nieklasyczna socjologia medycyny: praktyki medykalizacji jako praktyki władzy w ujęciu Michela Foucaulta. [W:] W stronę socjologii zdrowia. Red. W. Piątkowski, A. Titkow. Lublin, s. 181-193.

Buczkowski A. (2005). Społeczne tworzenie ciała. Płeć kulturowa i płeć biologiczna. Kraków.

Cahill H.A. (2000). Male Appropriation and Medicalization of Childbirth: a Historical Analysis. „Journal of Advanced Nursing” vol. 33, no. 3, s. 334-342.

Czerwiński M. (1987). Wstęp. [W:] M. Foucault, Historia szaleństwa $w$ dobie klasycyzmu, przeł. H. Kęszycka. Warszawa, s. 5-12.

van Dijk T.A. (1993). Principles of Critical Discourse Analysis. „Discourse \& Society” vol. 4, no. 2, s. 249-283.

van Dijk T.A. (2009). Critical Discourse Studies: A Sociocognitive Approach. [W:] Methods of Critical Discourse Analysis. Red. R. Wodak, M. Meyer. London, s. 95-120.

Domańska U. (2005). Medykalizacja i demedykalizacja macierzyństwa. [W:] Zdrowie i choroba. Perspektywa socjologiczna. Red. W. Piątkowski, W.A. Brodniak. Tyczyn, s. 311-322.

Fijałkowski W. (1974). Rodzi się człowiek. Warszawa.

Foucault. M. (2002). Porzadek dyskursu. Wykład inauguracyjny wygłoszony w Collège de France 2 grudnia 1970, przeł. M. Kozłowski. Gdańsk.

Gallagher E.B. (1976). Ideologia konsumpcji a opieka zdrowotna. [W:] Socjologia a zdrowie. Red. M. Sokołowska, J. Hołówka, A. Ostrowska. Warszawa, s. 191-211.

Gromkowska-Melosik A. (2013). Kobieta epoki wiktoriańskiej. Tożsamość, ciało i medykalizacja. Kraków.

Huckin T. (2002). Critical Discourse Analysis and the Discourse of Condescension. [W:] Discourse Studies in Composition. Red. E. Barton, G. Stygall. Hampton, s. 1-29.

Illich I. (1976). Limits to Medicine. Medical Nemesis: The Expropriation of Health. New York.

Jabłońska B. (2006). Krytyczna analiza dyskursu: refleksje teoretyczno-metodologiczne. „Przegląd Socjologii Jakościowej” tom II, s. 53-67.

Kubicka-Kraszyńska U., Otffinowska A., Pietrusiewicz U. (2006). O bólu porodowym i metodach jego łagodzenia. Warszawa.

Piątkowski W. (2002). W stronę socjologii zdrowia. [W:] W stronę socjologii zdrowia. Red. W. Piątkowski, A. Titkow. Lublin, s. 15-58. 
Podgórska J. (2005). Betonowe położnictwo. „Polityka” nr 43 (2527), s. 4-11.

Purdy L. (2001). Medicalization, Medical Necessity, and Feminist Medicine. „Bioethics” vol. 15, no. 3, s. 248-261.

Rasch V. (2007). Maternal Death and the Millennium Development Goals. „Danish Medical Bulletin" no. 54, s. 167-169.

Reiger K., Dempsey R. (2006). Performing Birth in a Culture of Fear: an Embodied Crisis of Late Modernity. „Health Sociology Review” no. 215, s. 346-373.

Rich A. (2000). Zrodzone z kobiety. Macierzyństwo jako doświadczenie i instytucja, przeł. J. Mizielińska. Warszawa.

Wagner M. (2006). Born in the USA. How a Broken Maternity System Must Be Fixed to Put Women and Children First. California.

Wertz D.C. (1996). What Birth Has Done for Doctors: A Historical View. [W:] The Medicalization of Obsterics: Personnel, Practice, and Instruments. Red. P.K. Wilson. New York, s. 7-24.

Zola I.K. (1972). Medicine as an Institution of Social Control. „Sociological Review” no. 20, s. 487-504 .

\section{Źródła intemetowe:}

Make every mother and child count; raport WHO z 2005 roku. http://www.who.int/whr/2005/en/ (dostęp: 29.03.2014 r.).

Wagner M., Ryby nie widza wody: potrzeba humanizacji porodu, przeł. A. Łokaj. http://www. rodzicpoludzku.pl/Wiedza-o-porodzie/Ryby-nie-widza-wody-potrzeba-humanizacjiporodu.html (dostęp: 29.03.2014 r.).

\section{Reflections on Pregnancy and Childbirth. The Perspective of C ritic al Disc ourse Analysis}

\section{Summary}

The main thesis of the work is the claim that medicine, supported by scientific authority and institutional power of the state has played a dominant role in the "act of violence", which resulted in the fact that pregnancy and childbirth have become definable in terms of medicine and medical procedures, as well as area, as some strands of feminist emphasized, of male (medical) dominance over female body. By referring to the theoretical and methodological direction of "critical discourse analysis" (CDA - Critical Discourse Analysis) and analyzing the concept of the "knowledge-power" relationship by M. Foucault, attempts to impose a vision of pregnancy and childbirth was considered as a part of a broader strategy aimed at "pacification" of society as such. According to Foucault, since the society came to be seen as a resource, including economic, featured by measures of fertility, birth or health, body, reproductive and sexual area became a matter of public concern and conscious population management. At that time, medicine has become a tool of power, and actually by creating some social meanings, creating a peculiar way of thinking and social attitudes, it became a kind of power. From this perspective, the approach to pregnancy, 
childbirth, and women giving birth and the procedures and solutions used during labor are the result of institutional coercion, the fight between the applicable "truths": "How women gave birth, who helped them, how and why? These are not just questions about the history of obstetrics: these are political questions".

The text presents selected mechanisms of formation of the medical discourse that has dominated thinking about pregnancy, childbirth and the woman giving birth in most developed countries. In a broader sense, the medical discourse is trying to "appropriate" social space by treating complex phenomena in terms of biomedicine, mostly as a disease risk factor or disorder. With regard to women, this means that the natural stages of life - pregnancy, childbirth, feeding and interaction with the child, have been largely excluded from the socio-cultural and subjected to medical interpretation. In case of pregnancy and childbirth medical discourse manifests itself particularly in the impoverishment understanding of what is motherhood, bringing pregnant women to a passive object of medical intervention, interpretation of pregnancy and childbirth as a threat, standing against the women's sense of agency and being competent, and thus the loss of mental satisfaction form childbirth, and fear as a motivation to undergo unjustified interventions, subordinate role of midwives in relation to doctors and the general belief that safe childbirth takes place in a hospital, etc. 